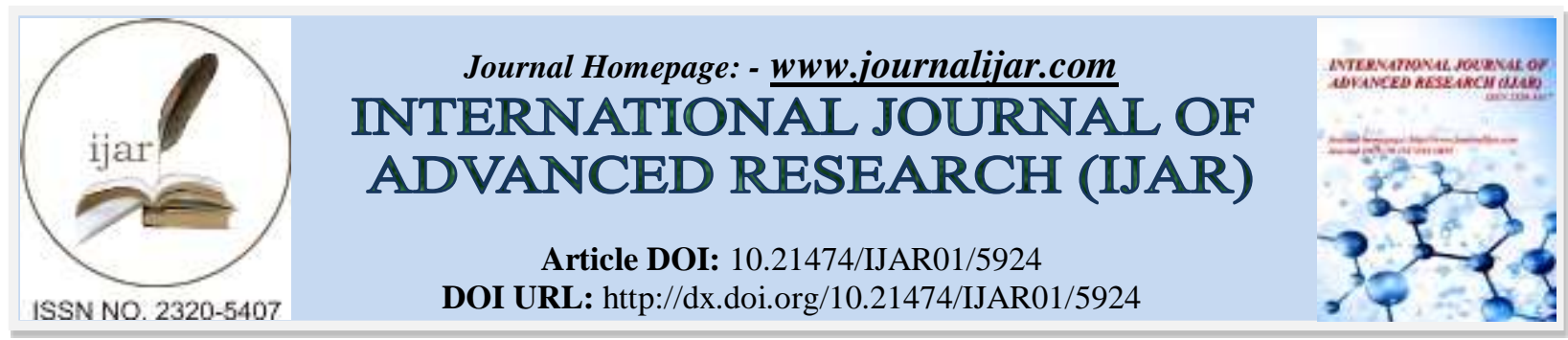

RESEARCH ARTICLE

\title{
BIO-DIVERSITY CONSERVATION AND EMPLOYMENT GENERATION BY SERICULTURE AT- RAIGARH (C.G.) INDIA.
}

Santosh k. Dewangan.

Joint Collector, Narayanpur, District Narayanpur (Chhattisgarh) India.

\section{Manuscript Info}

Manuscript History

Received: 20 September 2017

Final Accepted: 22 October 2017

Published: November 2017

Key words:-

Employment, Diversity, Sericulture,

Tribal, Tasar.

\begin{abstract}
Sericulture is an eco-friendly agro-based labor intensive and commercially attractive economic activity, falling under cottage and small-scale sector. Sericulture enterprise in its totality is a long chain industry from mulberry cultivation to fabric making. Sericulture plays a key role in the uplift of rural population both socially and economically. Sericulture is one of the prominent enterprises, which provided full time employment to the entire family, offering high income and better standard of living. Seri-biodiversity refers the variability in sericigenous or silk producing insects and their host plants. As in 2015-16 the total raw silk production in the country is 28523 MT and goes up to 30348 MT in 2016-17 with employment generation of 85.16 lakh person. Chhattisgarh has 27 districts and all the districts have Sericulture activities. Three types of sericulture activities viz., Tasar, Mulberry \& Eri are being implemented by the State. Raigarh district has total area of 2022.6 ha Daba tasar farming under with production of 15,93,7,216 lakh cocoons 63, 6375 beneficiaries. In view of the importance of sericulture enterprise, the paper tries to enlighten and discuss the significance of sericulture and strategies to be taken for the employment generation in Indian sericulture industry. Present paper explores the possible employment opportunities derived from problem analysis in the study area. The paper highlights the sericulture is a way for livelihood opportunities in Raigarh district. The study concludes with some suggestions to improve the feasibility of sericulture in long term
\end{abstract}

Copy Right, IJAR, 2017,. All rights reserved.

\section{Introduction:-}

The word "sericulture" is derived from the Greek word "sericos" meaning "silk" and "culture" meaning "rearing". Sericulture is a labour oriented, low investment, agrarian, small scale industry which suits both marginal and small land holders because of its high returns, short gestation period and it creates opportunity for women employment. "Silk is the queen" of textiles no other fibre is a match to natural silk (Parimala, 2009). Sericulture was introduced in India about 400 years back and the industry flourished as an agro- industry till 1857, with an annual production of two million pounds of silk fibre. The industry survived the onslaught of the Pebrine disease during the period from 1857 to 1895 (Mohanty, 1998). Sericulture is divided in two sectors namely farm and industry. The farm sector involves growing silkworm's food plants, rearing silkworm to produce cocoons and eggs. Reeling,twisting, dyeing, printing, finishing, knitting form the industry sector (Srivastav P. K et. al. 2005). Sericulture, the production of silk 
worms and thus ultimately of silk fibre (Ganga and Chetty, 1991), has become a promising rural activity in India because of its minimum gestation period, minimal investment, maximum employment potential and quick turnover for investment (Kasi, 2000, 2009a and 2009d). Sericulture is rearing of silkworm for production of cocoons which is the raw material for the production of silk (Kamili and Masoodi, 2000). Sericulture broadly comprises interlinked activities such as food plant cultivation and maintenance to feed the silkworms, silkworm rearing to produce the silk cocoons, reeling the cocoons for unwinding the silk filament, yarn making, weaving and processing of fabric (Ahmed, S.A. et.al. 2011). Sericulture is the rearing of silkworms for the productions of cocoons which forms the raw material for producing raw silk. Sericulture originated in China and the Chinese kept it secret for over 3000 years before it leaked to India, Koria and other nations in Asia and Europe (Krishnaswami et.al. 1972; Ball, 2009; He, 2010). Sericulture activity brings regular income to the community without any bias of caste, creed, gender, or religion. A remarkable feature of this activity is its egalitarianism - sericulture farmers, rich and poor, earn the same income from it. As women has a crucial role in the activities of sericulture, it equally creates opportunities and make them independent socially, economically, politically, and otherwise (Goyal, 2007; Pillai \& Shanta, 2011; Thomas, Muradian, de Groot, \& de Ruijter, 2010; Vijayanthi, 2002). Sericulture is a labor intensive industry in all its phases. It can generate employment up to 11 persons for every kg of raw silk produced. Out of which more than 6 persons are women. More than 60.00 lakh persons are employed as full time workers in the production chain out of which 35-40 lakh persons are women (Rama Lakshmi C.S. 2007). India is the second largest producer of silk in the world next only to China. Karnataka is the leading sericulture state which contributes around 50 per cent of the total silk production in India. Sericulture has a complementary effect on other agricultural enterprises. It is estimated that the indirect effect of sericulture to the farm income is about 25 per cent (Mattigatti and Iyengar, 1995). Sericulture plays an important role in transformation of rural economy as it assures regular employment and periodic returns round the year (Lakshmannan et al., 1998). Sericulture in India is a fairly organized cottage industry, largely rural based and labour intensive. Cultivation is spread Over 22 states, covering 172000 hectares. Sericulture provides employment to more than 6 million people across 54000 villages, which operate 258000 handlooms and 29340 Power looms, producing 5 million square meters of silk fabric per annum (Dewangan S. K. et. al. 2011). Sericulture is an integral part of tribal life having immense traditional and ethnic value in their socio-economic structure practiced by about 1.5 lakh tribal populace in the states of Jharkhand, Chhattisgarh, Orissa, Madhya Pradesh, Utter Pradesh, West Bengal, Bihar, Maharashtra and Andhra Pradesh (Shetty et al 2007).

The word "Tasar" has taken its origin from the Sanskrit word "Trasara" meaning "shuttle". Tasar is a type of silk produced by the wild silk moth or giant silk moth, which is termed as tussah, tassar, or tussora (Suryanarayana and Srivastava, 2005). Tussar Silk is also known by its Sanskrit name 'Kosa Silk' and produced mainly in Jharkhand state of India (Nakpathom et al 2009; Pilanee Vaithanomsat et al 2008). Tussar is valued for its rich texture and natural deep gold color. They feed mainly on primary food plants viz., Shorea robusta (Sal), Terminalia arjuna (Arjun) and Terminalia tomentosa (Asan) besides other secondary and tertiary food plants (Suryanarayana et al., 2005). Indian tropical tasar (Tussah) is copperish color, coarse silk mainly used for furnishings and interiors. It is less lustrous than mulberry silk, but has its own feel and appeal. Oak tussar is a finer variety of tussar silk (Vepari et al 2007). The characteristic of tussar silk has rich coarse texture, light and airy. It gives a cool comfort feeling and also delicate and stiff in nature. It has different natural shades (Wang et al 2006; Yang Cao et al 2009). Sericulture plays a key role in the uplift of rural population both socially and economically (Sreenivasa and Hiriyanna, 2014), best suited to both marginal and small scale landholders because of its low investment, high assured returns, short gestation period, rich opportunities for enhancement of income and creation of family employment throughout the year (Raveendran et al., 1993; Srinivasa et al., 1998, 2014; Hajare et al., 2005).

Seri-biodiversity refers the variability in sericigenous or silk producing insects and their host plants. (Srivastava, P.K.\& Thangavelu, K.2005). Fairly good numbers of references are on record about Seri-biodiversity and their potential as a source of natural silk in Indian subcontinent (Arora \& Gupta 1979, Chinnaswamy 2001, Nassig et. al.1996). The wild Silk moths play an important role in the conservation and utilization of biodiversity as reported by Frankel 1982, Peigler 1993, and Kioka 1998,Thangavelu 1992, Alam et.al.1993, Narsimhana 1998, Akai 1998, Satpathy and rao 2003, Mohan rao et.al.2004, Kirsur and Krishna rao 2003, Shankar rao et.al.2004, Rout et.al.2003, Mitra and Moon 2009. The 44 ecoraces of insects feeds majorly on nature grown food plants available over Jharkhand, Orissa,Chhattisgarh,Bihar, Madhya Pradesh, Andhra Pradesh, West Bengal and Maharashtra states (Shrivastava, A.K. et.al. 2002, Thangavelu, K. et.al.2000). In Chhattisgarh Tropical Tasar and mulberry are reared on commercial scale. Tasar is realy named as Kosa. Sericulture is being practiced by the tribal of traditional Districts of Baster, Raigarh, Bilaspur and Surguja (Gupta Rakesh et al, 2008). Sericulture activities covered 43760 acres. The total number of Tasar center is 285 and mulberry gardens are 117. The total beneficiaries 
are 51310 in numbers out of them 32429 are scheduled Tribe (Dewangan S.K. et al.2010). India continues to the second largest producer of silk in the world and has $16.58 \%$ share in global raw silk production. Among the four varieties of silk produced as in 2012-13 Mulberry accounts for 18715 MT, Eri 3116 MT, Tasar 1729 MT, and Muga 119 MT of the total raw silk production of 23679 MT in the country. In 2013-14 the production increased up to 26480 MT and goes up to 30265 MT in 2016-17. The employment generation in the country is raised to 8.51 million persons in 2016-17 compared to 7.85 million persons in 2013-14. (Annual Report of Sericulture C S B, Bangaluru, 2017). In recent times, India progressed tremendously on developing various technologies on production and protection of both mulberry and silkworm, aiming at drastic shift from cross-breed silk production to bivoltine hybrid silk production (Meenal, 2008). The knowledge and adoption of recommended sericultural technologies are influenced by various socio-economic factors like age, education, economic condition of the farmers etc., (Priyadarshini \& Vijayakumari, 2013).

\section{Aims and Objectives:-}

1. Identification of the areas where the tribal populations have been directed to adopt sericulture practices for their livelihood.

2. Since how long this population is practicing sericulture.

3. What percentage of male, female and children are involved in this process?

4. By preparing a questionnaire, data on different elements of sericulture practices and aspects of economy in terms of their economic growth will be collected.

\section{Methodology:-}

Raigarh district are major tasar growing area where tribal are engaged in sericulture activity. Tasar silkworm rearing has been going on since 1956-57 and rearing of mulberry silkworm started in the year 1982-83. Since sericulture activity covered 312042 acres, therefore the total beneficiaries are 5739 out of them 3347 are scheduled tribe. Dharamjaigarh, Lailunga and Kharasia is a rural populous block in Raigarh district.

For the present study, three Block viz., Dharamjaigarh, Lailunga and Kharasia of Raigarh district were selected and from each block 100 farmers were selected randomly $(\mathrm{n}=100)$. In total, 300 farmers were selected from the three selected Blocks. The farmers were post classified into main and additional based on the engagement of employment. Study was conducted through personal interview method by the aid of a pre-prepared and tested questionnaire. Data on various factors such as age, education, family size, experience, extension contact, cocoon yield, cocoon price, consumption of DFLs/acre, area under mulberry, and level of adoption with respect to production and protection of both mulberry and silkworm were collected and recorded. Primary and secondary data was analyzed using various statistical tools viz., mean, mode and median.

\section{Result and discussion:- \\ 4.1 status of house}

In Lailunga block the status of the Kachha house are minimum i.e. 97 and in Dharamjaigarh \& Kharasia all respondents have 100 Kachha houses that is Maximum in no. In Lailunga block the status of the Pakka house are maximum 03 and in Dharamjaigarh \& Kharasia all the respondents have no Pakka house. In Lailunga block the status of the ownership of house i.e. 99 and in Dharamjaigarh \& Kharasia all the respondents have their own house.

\subsection{Working Member In Family}

It is observed that in Lailunga \& Kharasia block the status of the occupation (working member in family) are minimum i.e. 2.49 and Maximum in Dharamjaigarh block i.e. 2.54. In Dharamjaigarh block no respondent has adopted sericulture as primary or main occupation, Similarly in Lailunga block 18 and in Kharasia block 1 respondents while 100 respondents has adopted as secondary occupation in Dharamjaigarh, 82 from lailunga and 99 from Kharasia block.

\subsection{Man Days Earn From Sericulture}

In block Dharamjaigarh 26 respondents received employment for duration of 100-150 days and 74 respondents received 151-200 days. 201-300 days employment receiver respondents and 301-365 days receiver's respondents are nil. Similarly in block Lailunga 32 respondents received employment for100-150 days and 65 respondents received 151-200 days. 201-300 days employment received by 3 respondents and 301-365 days employment receiver's respondents are nil. Also in block Kharasia 37 respondents received employment for 100-150 days and 42 
respondents received 151-200 days.201-300 days employment received by 16 and 301-365 days employment receiver's respondents are 5. Almost all respondents replied that the employment site is situated their own village where they got employment from sericulture.

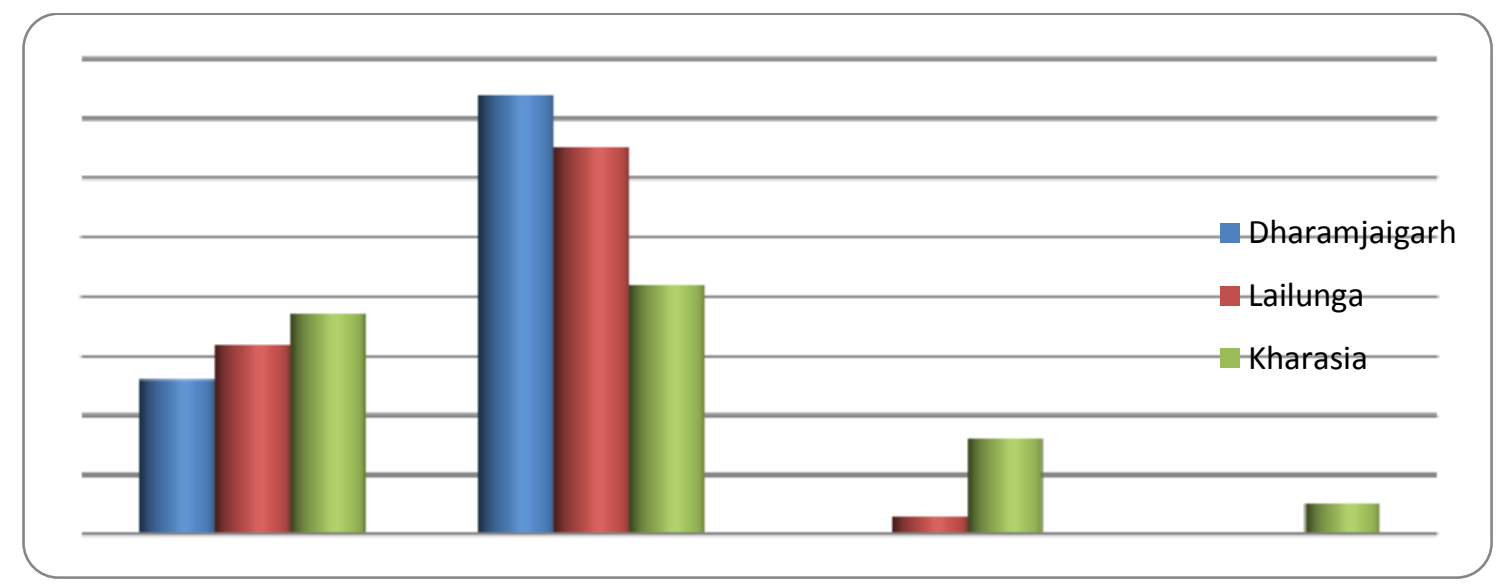

Graph-1: Man Days Earn From Sericulture

\subsection{Income And Expenditure}

The total average income from all source is minimum in Kharasia block only Rs. 3660/- and maximum in Lailunga block Rs. 3840/- while in Dharamjaigarh it is worth as Rs. 3770/-. From the forest minor produce collection and disposal (once in a year) the average income of the respondents has been estimated of Kharasia Rs. 5750/-, Dharamjaigarh Rs. 5350/-and Lailunga it is Rs. 5950/- respectively. An average expenditure of the respondent by all means is approximately in Dharamjaigarh block Rs. 2665/- while as Kharasia Rs.2410/-, and Lailunga Rs. 2380/-.

\subsection{Cocoon Crop In A Year}

It is observed that 18 respondents from Dharamjaigarh while 15 respondents from Lailunga and 17 from Kharasia block take only 1 crop in a year. In Dharamjaigarh block 11 respondents take 2 crops in a year, from Lailunga block it covered 12 respondents whereas in Kharasia block 23 are reported. From Dharamjaigarh block 71 respondents, from Lailunga 73 and from Kharasia 60 respondents take 3 crops in a year. All respondents get DFLs from Sericulture centers, and their demand of dfls is easily fulfilled by the State sericulture department.

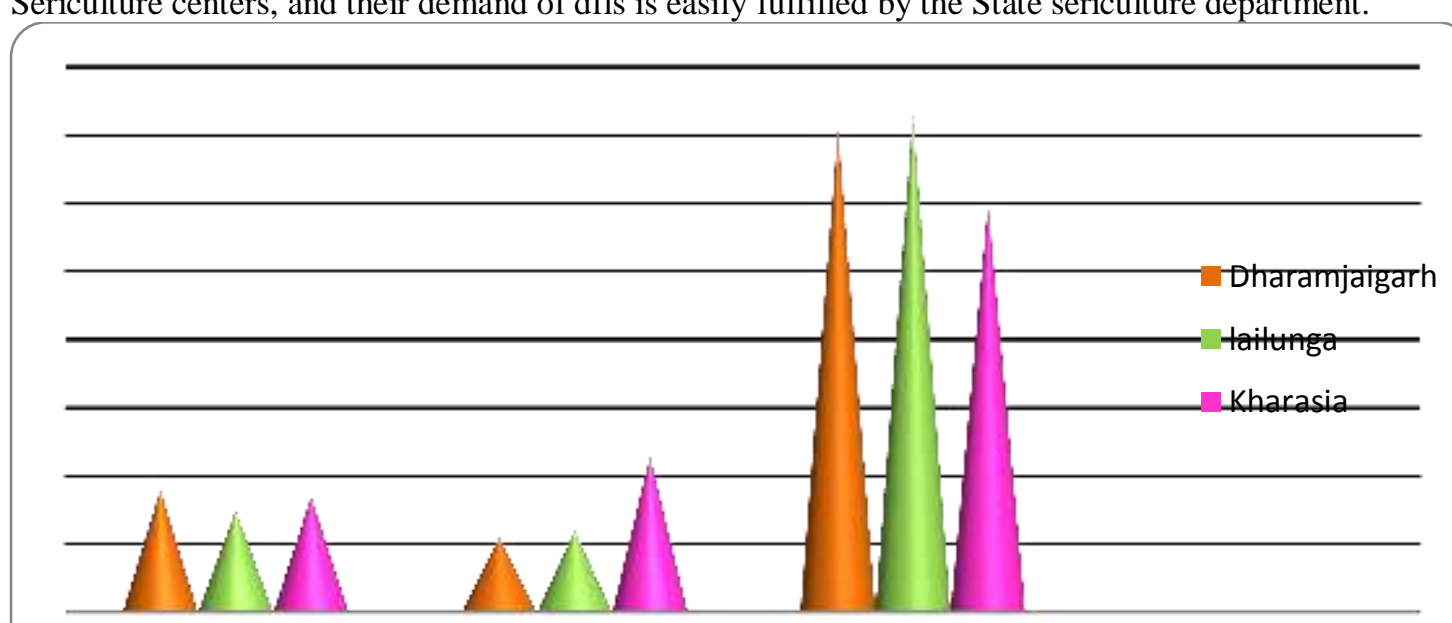

Graph-2: Cocoon Crop In A Year

\subsection{Cocoon Production And Profit}

The number of cocoon in each crop are produced in Dharamjaigarh block are 6350, in Lailunga block 5900, in Kharasia block 7800. The economic gain by the respondent from sail of cocoon from Dharamjaigarh block are 5160 Rs., from Lailunga block 5720 Rs., and from Kharasia block 5960 Rs. The yearly production of cocoons by the respondent of Dharamjaigarh block is 18900 numbers, in Lailunga block 18300 number, in Kharasia block 20550 
number. Average annual income from the yearly production of Cocoons has been estimated about 16980 Rs. From Dharamjaigarh block and in Lailunga block i.e. 18220 Rs. and in Kharasia 16140 Rs. The similar results were also reported by Hongkarnjanakul (1990), Mundra and Kothari (1992), Manju (1997), Kumar (2001), Dutt and Chole (2002), Suresh (2004), Sujatha et al. (2006), Geetha and Devi (2008), Balakrishnappa and Rajan (2010), Ali (2010), and Todmal et al. (2013).

\subsection{Domestic Expenditure}

In the category of Liquor and Narcotics, 83 respondents from Dharamjaigarh block, 72

from Lailunga and 12 respondents from Kharasia block consume there expenditure in liquor. On Tobacco maximum expenditure is incurred by the respondents of Lailunga and Dharamjaigarh block 69 followed by Kharasia 24 respondents. Same as on Gudakhu 69 from Dharamjaigarh and 67 from Lailunga, whereas 46 from Kharasia block, domestic expenditure has been incurred. In Dharamjaigarh block 05 respondents incurred expenditure on Gaanja whereas 01 respondents from Kharasia block expenditure on the same. Respondents from Lailunga block on same are nil.

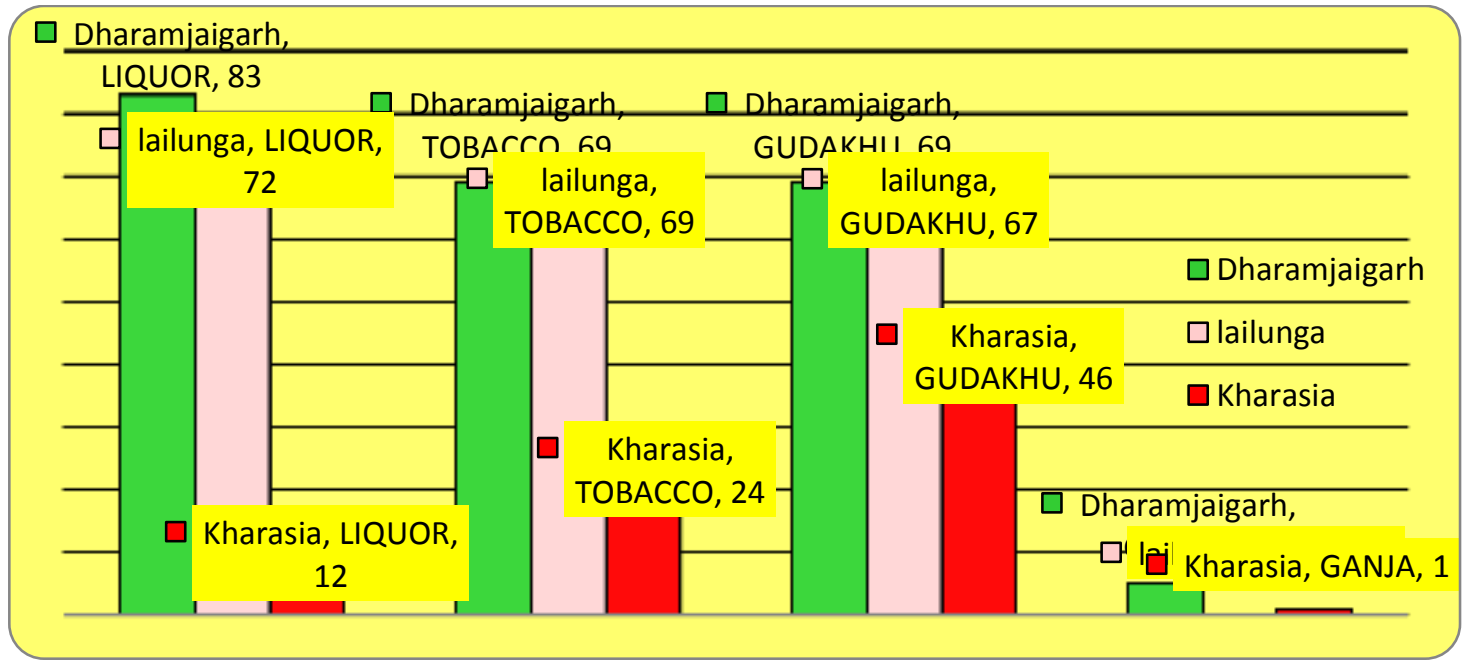

\subsection{Types Of Livestock (Milching)}

Graph-3: Domestic Expenditure

In the study area 24 respondents have cow in Dharamjaigarh, 25 rspondents in Lailunga whereas 14 respondents from Kharasia. 4 respondents have Buffalos in Dharamjaigarh, 5 in Lailunga and 3 in Kharasia. 10 respondents have shegoats in Dharamjaigarh 32 respondents in Lailunga and 7 in Kharasia. As a live stock engaged in household burden in Dharamjaigarh block, Ox- by 43 respondents and in Lailunga 88 respondents and in Kharasia 34 respondents. In Dharamjaigarh block 14 respondents have poultry whereas in Lailunga block it covers 37 respondents and in Kharasia 16.

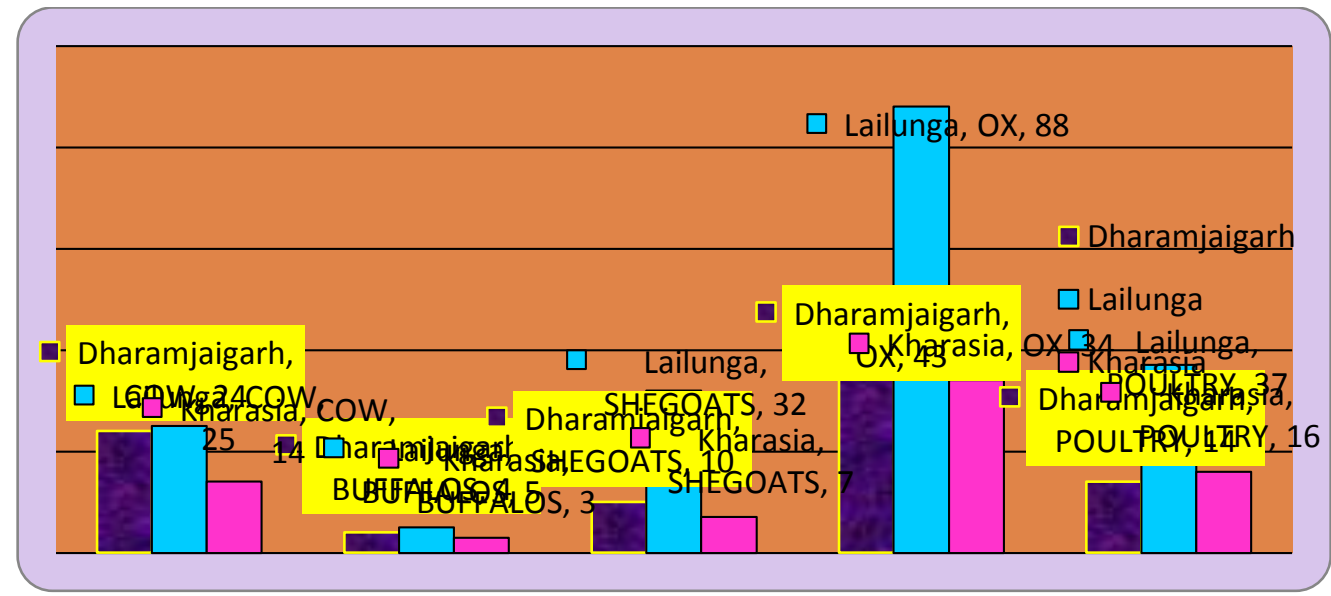

Graph-4: Types Of Livestock (Milching) 


\subsection{Movable And Immovable Property}

It is observed in the study that in the status of movable property point of view the 66,42 and 23 respondent from Lailunga block have livestock, Agriculture equipments and vehicles whereas in Dharamjaigarh block 93, 32 and 03 respondents have same and in Kharasia block they counted as 21, 13 and 16. In the mode of immovable property from the Lailunga block 57 respondent have cattle house, 68 have agricultural land, 62 have house and 02 have well or biogas plant. In Dharamjaigarh block the same manner 41, 46, 44 and 04 respondent and in Kharasia block they numbered as 24, 15, 42 and nil. The fixed assets earned from old occupation were estimated as Land and Building by 53 and 46 respondents from Lailunga block whereas it is 80 and 74 respondent from Dharamjaigarh block and 49 and 55 by Kharasia block.

\subsection{Status Of Occupation:}

It is observed that 58 respondent from Lailunga block are adopted agriculture as main occupation, 35 as agricultural labour whereas in Dharamjaigarh block 71 respondent adopted agriculture and 07 agricultural labour as main occupation and in same manner 59 and 36 respondent from Kharasia block. It is notable that in Lailunga block in all respondent family 148 male and 131 female human communities engaged in sericulture. In Dharamjaigarh block total 160 male and 147 female from the respondent family are engaged in sericulture and in Kharasia block 118 male and 104 female are engaged. The main occupation related to sericulture is wormiculture (Rearing), agriculture and field formation (preparation) are adopted by respondent of study area. The economic status in old occupation was normal for 72 respondents, bad for 08 and very poor for 20 respondent of Lailunga block whereas it is measured normal for 82 respondents, bad for 18 respondents of Dharamjaigarh and in Kharasia block 74 normal, 24 bad and 2 respondents are very poor condition in old occupation. The average annual income from old occupation was estimated as Rs. 19350/- for Lailunga and Rs. 20950/- for Dharamjaigarh block and 21800/- for Kharasia block. The similar results were also reported by Aiyaswamy (1980) and Kulkarni (1982),Giridhar et al.(1986), Hongkarnjanakul (1990), Limunggura and Boonchoo (2007), Geetha and Devi (2008), Malathesh et al. (2009), Balakrishnappa and Rajan (2010).

\subsection{Disease Affected To Host Plant}

91 respondents From Dharamjaigarh, 92 from Lailunga and 97 from Kharasia block rear on Terminelia arjuna. 75 respondents from Dharamjaigarh, 78 from Lailunga and 97 from Kharasia replied that host plants are affected by Matamari Disease. 61 respondents from Dharamjaigarh block, 62 from Lailunga and 97 from Kharasia block agree that the plants are affected by stem borer where as only 29 respondent from Dharamjaigarh 54 from Lailunga and nil from Kharasia block for leaf spot and 3 respondents from Lailunga and 4 from Dharamjaigarh block agree that plants affected with Root rot. All respondents answering that sericulture work are better than others.

\subsection{Cause Of Loss}

295 respondents had been bore a loss from Sericulture and 05 had not suffered. It indicates the hardship and risk involved in it. Almost all attributed the loss due to fluctuation of atmospheric and adverse weather conditions viz. heavy rains; high humidity and high temperature cause disease which leads to a complete failure of crops.

\begin{tabular}{|l|l|l|l|l|}
\hline S.n. & Cause of loss & Dharamjaigarh & Lailunga & Kharasia \\
\hline $\mathbf{1}$ & Heavy Rain & $\mathbf{8 2}$ & $\mathbf{8 8}$ & $\mathbf{9 8}$ \\
\hline $\mathbf{2}$ & High Temperature & $\mathbf{3 1}$ & $\mathbf{4 0}$ & $\mathbf{4 3}$ \\
\hline $\mathbf{3}$ & Storm & $\mathbf{2}$ & $\mathbf{8}$ & $\mathbf{3 0}$ \\
\hline $\mathbf{4}$ & Disease & $\mathbf{9 2}$ & $\mathbf{8 9}$ & $\mathbf{8 4}$ \\
\hline $\mathbf{5}$ & Pollution & $\mathbf{2}$ & $\mathbf{6}$ & $\mathbf{2 0}$ \\
\hline
\end{tabular}

\subsection{Sericulture And Risk Factor}

Out of 300 respondents only 6 respondents get compensation from government whereas 294 denied. All respondents are received full cooperation from the sericulture department. Only 16 respondent get loan as per their requirement and 284 not get. The total labor period in Dharamjaigarh block 8.08 hrs where as in Lailunga block i.e. 7.53 hrs and in Kharasia block $7.40 \mathrm{hrs}$. The average duration of sericulture occupation is In Dharamjaigarh 12.25, Lailunga 12.51, Kharasia 9.20 year.

\subsection{Displacements For Sericulture As Livelihood}

It is observed that in the Kharasia block 13 respondents have been displaced or Migrated for livelihood, 04 respondents from Dharamjaigarh block and nil from Lailunga block displaced. 08 respondents from Dharamjaigarh and 39 from Kharasia block feel that sericulture has affected their traditional business/occupation. 


\subsection{Sericulture And Social Impact}

It is observed that all the respondents attributed the following impact by Sericulture - Conservation of environment, No cutting and felling of trees, Interstate migration is checked, Local employment is generated. It served as additional income generating source, Regular savings habit has been developed, want to attach continue with the sericulture. It is suited to their lifestyle. The work is simple and can be done without any cost. Can serve better for the additional income generation and pave the way for the local employment generation. All respondents agreed that their economic status has changed. It has been estimated that the annual income rose up to an average of Rs 19800/respondent in Lailunga and in Dharamjaigarh block Rs. 20200/- and 18850 for Kharasia.

\subsection{Suggestion For Change}

It is observed in the study area that 67 respondents from Dharamjaigarh block and 55 from Lailunga and 66 from Kharasia block suggest for change in field work area. 20 respondents from Dharamjaigarh, 25 from Lailunga and 16 from Kharasia block suggest for change in rearing. 28 respondents from Dharamjaigarh, 45 from Lailunga and 66 from Kharasia block suggest for change in training. 23 respondents from Dharamjaigarh block and 37 from Lailunga and 20 respondents from Kharasia block suggest for change in facilitation. 69 respondents from Kharasia block suggest for change in Technical assistance, rest two block respondents have no remarks. 15 respondents from Kharasia block and 3 from Dharamjaigarh block want to change in marketing style, whereas respondents from Lailunga have no remarks.

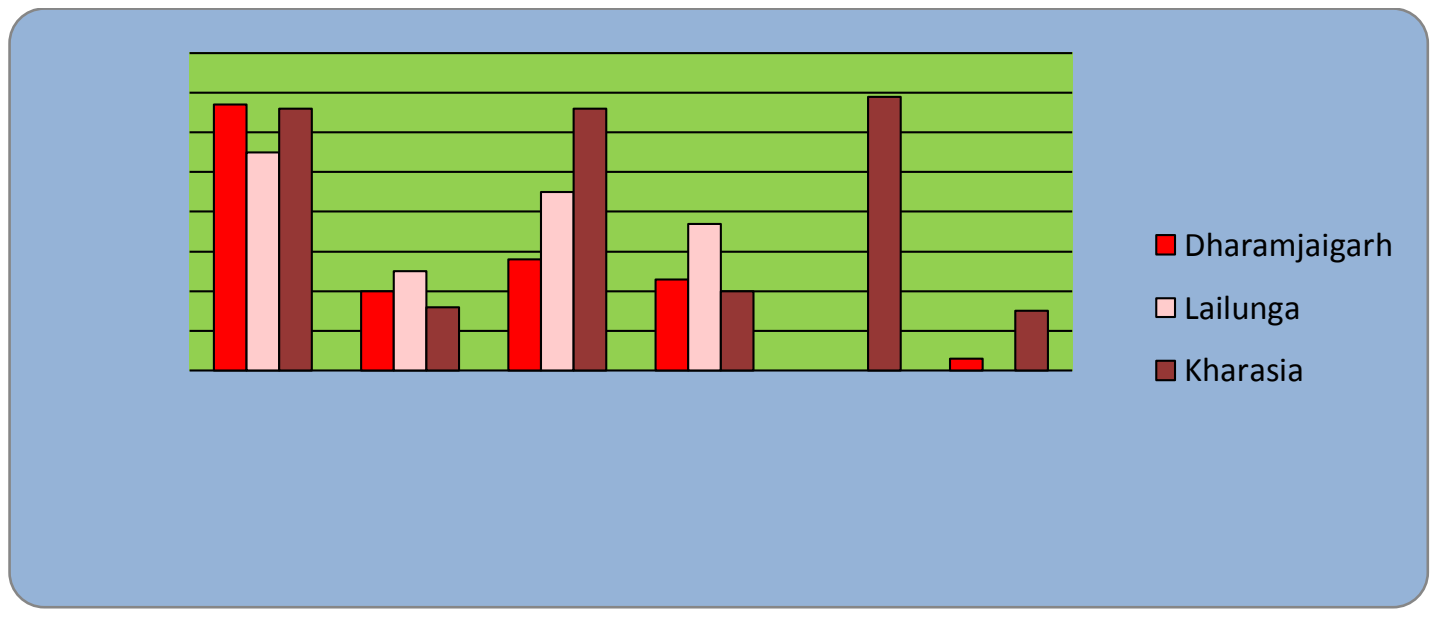

\section{Conclusion:-}

Graph-5: Suggestion For Change

Sericulture has provide downstream employment and income generation in rural and semi urban areas, high participation for low-income and socially under privileged groups, a larger role for women in development and huge potential for contribution to export earnings. This Sericulture sector is not only important for generating rural employment and preventing rural migration but also for protection and preservation of ecology, socio-economic change, heritage and socio-cultural values. It can engage members of the whole family and the work can be managed in addition to their day to day activities. Initiating sericulture by a farmer invariably leads is generation of further downstream employment in reeling and weaving either in house hold or organized sectors. Sericulture is the part of the agriculture activities. More than 7.85 million persons are engaged in various sericulture activities in 2013-14 in India and in 2016-17 it is remarked as 8.51 million persons. Tasar culture is practiced on the forest plants in wild condition. The advantage of tasar culture is that it does not require any investment of plantation, rearing appliances, electricity and other essentials like mulberry sericulture. Sericulture provides more than 50\% employment to the respondent in a year thus stops the inter-state migration. According to the MNREGA (Mahatma Gandhi National Rural Employment Guaranty Programme) population must receive 100 days employment in a year where as sericulture provides 151-200 days employment to respondent i.e., 54\%. Gapes in technology transfer and extension support, inadequate market accessibility, poor linkage among different stake holders, are observed as weakness of sericulture in study area. Income generation process of the silkworm rearers are threatened by some significant supply side constraints, which includes several types of inefficiency starting from technological inefficiency, cost inefficiency, labour inefficiency and market inefficiency 


\section{Acknowledgements:-}

The author express thanks to the tribal people, Sarpanch, local leaders, government officials, for their participation, co-operation and hospitality extended during field work.

\section{Declaration Of Conflicting Interests:-}

The author declared no potential conflicts of interest with respect to the research, authorship and/or publication of this article.

\section{Funding:-}

The author received no financial support for the research and /or authorship of this article.

\section{References:-}

1. Ahmed, S.A. et.al. 2011. Exploration of vanya silk biodiversity in north eastern region of India: Sustainable livelihood and poverty alleviation. International conference on Management, Economics and Social sciences, Bangkok. December.pp:485-489.

2. Annual Report of Sericulture 2017. Central silk Board, India, Bangalore.

3. Arora, G.S and Gupta, I. J. 1979. Taxonomic studies of some of the Indian non-mulberry silkmoths. Memoirs of Zoological survey of india. 1979, 16: 1-63.

4. Ball, P 2009. Rethink silk origin. Nature. 457: 935.

5. Chinnaswamy, K.P.2001. Sericulture biodiversity in india. Participatory biodiversity conservation in South Asia Region. Fonarem, Kathmandu, Nepal. 2001, Pp 54-61.

6. Dewangan S.K. et al. 2010. Socio economic upliftment of Tribal through Tasar sericulture- a study of Tamnar block of Raigarh district, C.G, India. World Academy of Science, Engineering and Technology, 72, pp: 481492.

7. Dewangan S. K. et. al. 2011. Sericulture - A Tool of Eco-System Checking Through Tribal. Journal of Environmental Research and Development, (6) 1, July-September.

8. Ganga, G. and Chetty, J. Sulochana 1991. An Introduction to Sericulture. Oxford and New Delhi: IBH Publishing Company.

9. Goyal, A. 2007. Women making choices: Masked but aware? Int. Journal of Gender Studies, 14, 409-437.

10. Gupta Rakesh et al. 2008. Tasar culture showed them the way, Indian silk,Feb p-20.

11. Hajare, T. N., Jadhav, A. D., Challa, O. \& Gajbhiye, K. S. 2005. Sericulture Empowers Women Farmer. Indian Silk, 25(4), 19-20.

12. He, J.H. 2010. Silk is China and China is Silk. A Response to Good et.al. 2009. Achaeametry, University of Oxford. 1475-4754.

13. Kamili, Afifa, $\mathbf{S}$ and Masoodi, Amin, M. 2000. Principles of temperate sericulture. Kalyani Publishers, Ludhiana, pp.257.

14. Kasi, Eswarappa 2000. Development and Change Due to Sericulture: A Village Study in Chittoor District. Hyderabad: University of Hyderabad.

15. Kasi, Eswarappa 2009a. Anthropology and Development in a Globalized India: Ethnography of Sericulture from the South. Newcastle Up on Tyne: Cambridge Scholars Publishing.

16. Kasi, Eswarappa 2009d. 'Socio-Cultural Dimensions of Sericulture: A Village Study from Andhra Pradesh'. In M. Moni and Suresh Misra -Rural India: Achieving Millennium Development Goals and Grassroots Development (pp. 298-313). New Delhi:

17. Krisnaswami, S; Madhava Rao, S; Suryanarayan,K and Sundaramurthy, T.S 1972. Sericulture manual 3silk reeling. FAO. Agricultural Services Bulletin 15.pp-122.

18. Lakshmanan,S., Mallikarjuna,B., Ganapathy Rao, R., Jayaram,H.and Geetha Devi,R.G.1998.Studies on adoption ofsericultural innovations at farmers level in Tamil Nadu - An empirical analysis. Indian J. Seri., 37 (1): 44-47.

19. Mattigatti, Raveendra and Iyengar, M.N.S. 1995. Role of different agricultural enterprises in agri-business with special reference to sericulture. Indian Journal of Sericulture, 33:163-165.

20. Meenal, R. 2008. Impact of adoption of bivoltine sericulture technologies by farmers in Erode District, Tamil Nadu. Ph.D. thesis. University of Mysore, Mysore.

21. Mohanty, P.K. 1998. Tropical Tasar Culture in India. Daya Publication House Delhi pp. 35-36.

22. Nakpathom, M., Somboon, B., Narumol, N, 2009. Papain Enzymatic Degumming of Thai Bombyx mori Silk Fibers, J Microscopy Society of Thailand, 23(1), 2009, 142-146. 
23. Nassig, W.A; Lempe, R.E.J. and Kger, S.1996. The saturnidae of Sumatra. Heterocera Sumatrana 1996, 10: 3-10.

24. Parimala, S.A.G. 2009. Role of women in sericulture. Kisan World pp. 33-34.

25. Pilanee Vaithanomsat, Taweesiri Malapant and Waraporn Apiwattanapiwat, 2008. Silk Degumming Solution as Substrate for Microbial Protease Production, Kasetsart J. (Nat. Sci.), 42, 2008, 543-551.

26. Pillai, M. P \& Shanta, N. 2011. ICT and employment promotion among poor women: How can we make it happen? Some reflections on Kerala's experience. Indian Journal of Gender Studies 18, 51-76.

27. Priyadarshini, B. M. \& Vijayakumari, N. 2013. A study on the knowledge and adoption level of improved sericulture practices by the farmers of Chittoor district. Indian Journal of Agricultural Science and Research (IJASR), 3(2), 43-46.

28. Rama Lakshmi, C.S. 2007 - Potential for participation of women in Sericulture sector.

29. Raveendran, N., Anitha. S., Parthipan, B. and Elangovan, S. 1993. Sericulture: A profitable farmventure. Agricultural Situation in India, XLVIII(1), 23-26.

30. Shetty, K.K. et.al 2007. Vanya silks of India-Exploring New Horizons, September 21.

31. Shrivastava, A.K. et.al.2002. Biotic diversity and genetic resource conservation of tropical tasar silkworm: National Imperative, Advances in Indian Sericultural Research, CSRTI, CSB, India, pp: 76-83.

32. Srivastava, P.K.\& Thangavelu, K 2005. Sericulture and Seri-biodiversity.Associated publishing Company, New Delhi

33. Shrivastav, P.K.et.al. 2005 Sericulture activities provide a perfect choice for the women. Sericulture and seribiodiversity.

34. Sreenivasa, B.T. \& Hiriyanna. 2014. A study on thefactors influencing adoption of new technologies in nontraditional sericultural area of Chitradurga District, Karnataka. Global Journal of Biology, Agiculture \& Health Sciences, 3(1), 239-243.

35. Srinivasa, G., Doddagadad, C. B., Jayaram, H. \& Geetha Devi, R.G. 1998. Technological practices of Sericulturists in non-traditional region of Karnataka. Indian Journal of Sericulture, 37(1), 57-60.

36. Suryanarayana, N. and Shrivastava, A.K. 2005. Monograph on tropical tasar silkworm. CTR\&TI, Ranchi (Jharkhand). pp. 1-20.

37. Suryanarayana, N., Kumar, R. and Gargi. 2005. Monograph on Indian Tropical Tasar silkworm food plants, Central Tasar Research and Training Institute, Central Silk Board, Ranchi, India. pp. 1-9.

38. Thomas, B. K; Muradian, R; de Groot, G; \& de Ruijter, A 2010. Resilient and resourceful? A case study on how the poor cope in Kerala, India. Jou. Of Asian and African Stud. 45, 29-45.

39. Thangavelu, K. et.al.2000. Management of tropical tasar silkworm and host plants germplasm. Proceedings of National workshop on management of sericultural germplasm for posterity. CSGRC.CSB, Hosur, India, pp: 72-90.

40. Vepari, C., Kaplan, D.L. 2007. Silk as a biomaterial, Progress in Polymer Science,32, 991-1007.

41. Vijayanthi, K. N 2002. Women's empowerment through self help groups: A participatory approach. Indian Journal of Gender Studies, 9, 263-274.

42. Wang, Y., Kim, H.J., Vunjak- Novakovic, G., Kaplan, D.L.2006 Stem cell- based tissue engineering with silk biomaterials, Biomaterials, 27, 2006, 6064-82.

43. Yang Cao, and Bochu Wang. 2009. Biodegradation of Silk Biomaterials, International Journal Mol Sci, 10, 2009, 1514-24. 